\title{
Impacts of fixed orthodontic appliance and clear-aligner on daily performance in adult patients with moderate need for treatment [Retraction]
}

Lin F, Yao L, Bhikoo C, Guo J. Impacts of fixed orthodontic appliance and clear-aligner on daily performance in adult patients with moderate need for treatment. Patient Preference and Adherence. 2016;10:1639-1645.
The corresponding author Dr Jing Guo, was not aware that his/her name had been used and did not give permission for the paper to be published. In addition, there were serious errors in the statistical tests used.
Patient Preference and Adherence

\section{Publish your work in this journal}

Patient Preference and Adherence is an international, peer-reviewed, open access journal that focuses on the growing importance of patient preference and adherence throughout the therapeutic continuum. Patient satisfaction, acceptability, quality of life, compliance, persistence and their role in developing new therapeutic modalities and compounds to optimize

\section{Dovepress}

clinical outcomes for existing disease states are major areas of interest for the journal. This journal has been accepted for indexing on PubMed Central. The manuscript management system is completely online and includes a very quick and fair peer-review system, which is all easy to use. Visit http://www. dovepress.com/testimonials.php to read real quotes from published authors. 